\title{
Lethal congenital contracture syndrome type 2
}

INSERM

\section{Source}

INSERM. (1999). Orphanet: an online rare disease and orphan drug data base. Lethal congenital contracture syndrome type 2. ORPHA:137776

Lethal cong enital contracture syndrome type 2 is a rare arthrogryposis syndrome characterized by multiple congenital contactures (typically extended elbows and flexed knees), micrognathia, anterior horn cell degeneration, skeletal muscle atrophy (mainly in the lower limbs), presence of a markedly distended urinary bladder and absence of hydrops, pterygia and bone fractures. Other craniofacial (e.g. cleft palate, facial palsy) and ocular (e.g. anisocoria, retinal detachment) anomalies may be additionally observed. The disease is usually neonatally lethal however, survival into adolescence has been reported. 